\title{
A large specimen and cuticles of Paripteris gigantea (Sternberg) Gothan from its type area Žaclér̆ (Pennsylvanian, Czech Republic)
}

\author{
ZBYNĚK ŠIMŮNEK
}

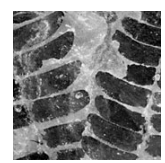

\begin{abstract}
An exceptionally well preserved, large fragment of Paripteris gigantea frond with "pseudo-pinnate" organization was found in Žacléŕ, Lampertice Member, Žacléř Formation (Intrasudetic Basin, Czech Republic). The single distal dichotomy of several basal "ultimate" pinnae is documented. The adaxial cuticle has elongated tetragonal cells oriented parallel to veins. The cells of the abaxial cuticle are probably polygonal with faintly discernible anticlinal walls; the haplocheilic stomata are sunken, partly covered by the proximal papillae of the subsidiary cells. Stomata are 22-30 $\mu \mathrm{m}$ long and 10-14 $\mu \mathrm{m}$ wide. Trichom bases are present on the pinnule margin and in the intercostal field of the abaxial cuticle. There are two concepts in the infrageneric classification of Paripteris. In contrast to traditional binomical classification (e.g., Cleal \& Shute 1995), Zhang et al. (1993) preferred to provisionally interpret all the so far described species as forms of Paripteris gigantea. - Key words: Paripteris gigantea, Pennsylvanian, cuticular analysis, Intrasudetic Basin.
\end{abstract}

S̆IMŮNEK, Z. 2009. A large specimen and cuticles of Paripteris gigantea (Sternberg) Gothan from its type area Žaclér (Pennsylvanian, Czech Republic). Bulletin of Geosciences 84(2), 269-282 (10 figures, 1 table). Czech Geological Survey, Prague. ISSN 1214-1119. Manuscript received December 16, 2008; accepted in revised form April 3, 2009; published online May 5, 2009; issued June 30, 2009.

Zbyněk Šimůnek, Czech Geological Survey, Klárov 3/131, 11821 Prague, Czech Republic; zbynek.simunek@geology.cz.

After the closing of the last deep mine, Jan Šverma, in Žacléř in 1992, mining activity restarted in 1999. The residual coal resources have been exploited by five quarries that were successively opened and later closed. Remains of $\mathrm{Pa}$ ripteris gigantea (Sternberg) Gothan are very common as isolated pinnules on bedding surfaces of mudstones that comprise the roof rocks and intercalations of the upper coal seams Nos 9, 10 and 11 of the Jan Šverma Coals, Lampertice Member, Žaclér Formation. Most of the finds came from the roof of the $9^{\text {th }}$ coal seam that has been mostly exploited by the quarries.

These remains of Paripteris gigantea were not the first finds in the Žaclér area. This species had been reported by Sternberg $(1821,1825)$, Němejc $(1933,1953)$, Němejc \& Šetlík (1950), Havlena (1953), Šetlík in Tásler (1979), Purkyňová (1986) and others from the same area. Additional available data are accessible in the unpublished reports of Rieger \& Šetlík, namely from boreholes drilled in the period from 1950 to 1970 . Invaluable information about the stratigraphical distribution of Paripteris gigantea can be found in the report about the construction of the pit Jan of Šverma mine (Rieger et al. 1962). However, we can trace the beginnings of investigation of this species back to the $19^{\text {th }}$ century, when Sternberg (1821) erected Osmunda gigantea on the basis of a specimen from the Žaclér area.

This species is very important from the point of view of migration of floral elements from Asia to Europe and North America (Laveine et al. 1993, 2000; Laveine 1997). Although this species has been known for nearly 200 years, the first reconstruction of the frond was made by Laveine (1967) and modified by Laveine et al. (1993). The specimen found in quarry No. 4 provides additional data on the gross morphology of this plant. The cuticles of Paripteris gigantea were firstly studied by Barthel (1961). Pteridosperm pinnules are usually weathered in the area of Žaclér quarries, therefore the cuticles were extracted from a specimen from borehole $\breve{S} 13$, situated less than $2 \mathrm{~km}$ SEE from the quarries (Spudil 1999).

\section{Material and methods}

Samples were collected in all five quarries in the area, whenever possible, systematically layer-by-layer (Fig. 1). The floras from individual layers were evaluated separately (Libertín et al. 2009). The thickness of the individual layers is between 5 to $10 \mathrm{~cm}$. Isolated pinnules of Paripteris Gothan have been frequently obtained from the spoil tip of 


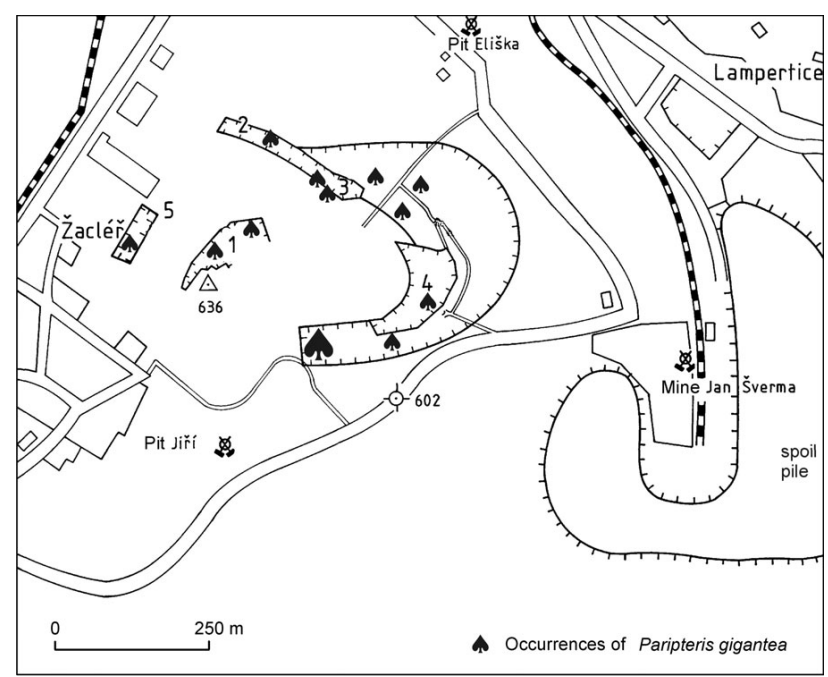

Figure 1. Map of area between Žacléř and Lampertice, the numbers 1-5 represent the quarries.

the Jan Šverma (formerly Marie-Julie) deep coal mine and also in small quarries that started to operate in 1999. The quarries (Nos 1 to 5 ; Fig. 1) mined the upper coal seams Nos 9, 10, and partly 11 (Fig. 2). Larger fragments of fronds are very rare and the frond fragment from the quarry No. 4 is exceptional. It represents parts of two penultimate pinnae on a slab $75 \mathrm{~cm}$ long and $75 \mathrm{~cm}$ wide preserved in roof rock mudstone. The studied Paripteris frond is from the Duckmantian Substage (Pennsylvanian Subsystem). The large fragment of Paripteris gigantea described here was excavated very carefully, and its component parts were wrapped and transported to the Czech Geological Survey building. These small fragments were stuck back together in the lab and studied. Now it is stored there under the No. ZŠ $144 a$, b.

The sample for cuticular study comes from rocks between the $10^{\text {th }}$ and $11^{\text {th }}$ upper coal seams of borehole $\breve{S} 13$, and is thus from the same stratigraphic level as that exposed in the quarries. Coalified pinnules were separated from the rock matrix by means of hydrofluoric acid (HF), then were bleached in Schulze's reagent (conc., or 20, respectively $40 \%$ solution of $\mathrm{HNO}_{3}$ with crystals of $\mathrm{KClO}_{3}$ ). The maceration time was 20 hours after which the cuticles were washed in diluted ammonium hydroxide $\left(\mathrm{NH}_{4} \mathrm{OH}\right)$ or $2 \%$ potassium hydroxide $(\mathrm{KOH})$, and finally rinsed in distilled water (see Kerp 1990 and Kerp \& Krings 1999). The cuticles were stained with safranin to accentuate cellular structures. The cuticles were embedded in glycerine gelatine slides.

\section{Geological setting}

The late Namurian to early Westphalian Žacléř Formation was deposited in the Intrasudetic Basin, one of the basins of the Sudetic area. The Intrasudetic Basin straddles the border between the Czech Republic and Poland. The oldest coal-bearing deposits belong to the Wałbrzych Formation of early Namurian age, and are preserved only in the Polish part of the Intrasudetic Basin. The sedimentation in the Czech part starts with the Blażkow Formation that was formed by coloured (mauve or maroon) rocks with a dominance of conglomerates. The thickness of this formation is several tens to a few hundreds of meters and its age is probably late Viséan to early Namurian. The unconformably overlying Žacléř Formation typically shows a cyclic development. Havlena (1956) defined 64 cycles of conglomerates, sandstones, siltstones, claystones and coal seams in the Lampertice Member, the oldest subdivision of this formation. The maximum thickness of this member is $680 \mathrm{~m}$ (Tásler et al. 1977). The thickness of a cycle varies from 3 to $30 \mathrm{~m}$ and the average thickness of a cycle is $11 \mathrm{~m}$. The Intrasudetic Basin is a typical intermountain basin without any marine influence (the Viséan marine influence is known only in a small area of the Polish part). The basement is formed by the Proterozoic and Early Palaeozoic crystalline rocks. The thickness of the Lampertice Member is approximately $550 \mathrm{~m}$ in the Jan pit (crossed hammers at "Mine Jan Šverma" in Fig. 1). The rocks exposed in quarries 1-5 belong to the upper part of this unit.

\section{Origin and terminology of the frond}

The frond architecture was designated and described by Laveine et al. (1993) and Laveine (1997) as "pseudopinnate". The frond is quite large, differing from other neuropteroid groups. The above-mentioned authors explained such a frond as having originated from repeated bifurcations of a "fundamental rachis" (primary entity, bearing simple entire pinnules) by an overtopping process. Therefore, all rachises, whatever their apparent variable order of subordination, are fundamentally homologous. The compound frond is developed through exclusively dichotomous and dichotomous-anisotomous bifurcations of rachises without any pinnatifid segmentation of the lamina. This means that lobate pinnules do not occur in this species. On the other hand "intercalated" pinnules are present on all rachises.

The terminology for a "pseudo-pinnate" frond is not satisfactory. The frond could be called a "partly ante-antepenultimate" frond, because only its proximal parts are ante-antepenultimate, whereas its distal parts are antepenultimate. Similarly, a lateral pinna could be called a "partly antepenultimate" pinna, because its proximal part is antepenultimate and its distal part is only penultimate. This is maybe a little bit confusing, because it is difficult to determine which part of frond the incomplete pinna comes from. 


\section{Systematic palaeobotany}

Class Pteridospermopsida

Order Medullosales (Trigonocarpales)

\section{Genus Paripteris Gothan, 1941}

Type species. - Paripteris gigantea (Sternberg, 1821) Gothan, 1941.

Paripteris gigantea (Sternberg, 1821) Gothan, 1941 Figures 3-10

1821 Osmunda gigantea Sternberg; Sternberg, vol. I, 2: tent. 33, pl. 22.

1825 Nevropteris gigantea (Sternberg). - Sternberg, vol. I, 4: tent. 16.

1831 Neuropteris gigantea (Sternberg) Sternberg. - Brongniart, vol. I, 5, p. 240, pl. 69.

1933 Neuropteris gigantea (Sternberg). - Stockmans, pp. 41-45, pl. 13, figs 1, 1a, 1b, pl. 14, figs 1-4, pl. 15, figs $1-2 b$.

1941 Neuropteris gigantea Sternberg. - Arnold, p. 70, pl. 1, fig. 5 .

1944 Neuropteris pseudogigantea Potonié. - Bell, pp. 80, 81, pl. 33, figs 1, 2.

1953 Paripteris gigantea (Sternberg). - Gothan, p. 61, pl. 34, figs 1, 2, pls 35, 36 .

1953 Neuropteris gigantea (Sternberg). - Havlena, pp. 44-51, pl. 4, pl. 5, figs 1, 1a, 2.

1959 Neuropteris gigantea (Sternberg). - Crookall, pp. 132-139, fig. 47 , pl. 54, fig. 3 .

1961 Neuropteris gigantea (Sternberg). - Barthel, pp. 830, 831; pl. 3, figs 6-13, pl. 4, figs 1, 2.

1967 Paripteris gigantea (Sternberg). - Laveine, pp. 250-259, pls 70-72.

1993 Paripteris gigantea (Sternberg). - Laveine et al., pl. 1, figs 1,3 , 4, pl. 4, fig. 9, pl. 7, fig. 1, pl. 8 .

1993 Paripteris gigantea f. gigantea (Sternberg). - Zhang et al., p. 27, pl. 24, figs 1-3, pl. 29, fig. 7.

1995 Paripteris gigantea (Sternberg) Gothan. - Cleal \& Shute, p. 28

1997 Paripteris gigantea (Sternberg). - Laveine, pp. 160, 161.

2003 Paripteris gigantea (Sternberg) Gothan f. gigantea. Laveine et al., p. 510, pl. 11, figs 1-4, 6-9.

Description of the holotype. - The holotype comes from Žaclér and is stored in the National Museum in Prague under the No. E 4672 (see Fig. 3). It is preserved in grey micaceous mudstone. The slab is $380 \mathrm{~mm}$ long and $280 \mathrm{~mm}$ wide. This specimen was figured by Sternberg (1821) on pl. 22, but only part of the specimen was shown. On Sternberg's illustration, only five "ultimate" pinnae are

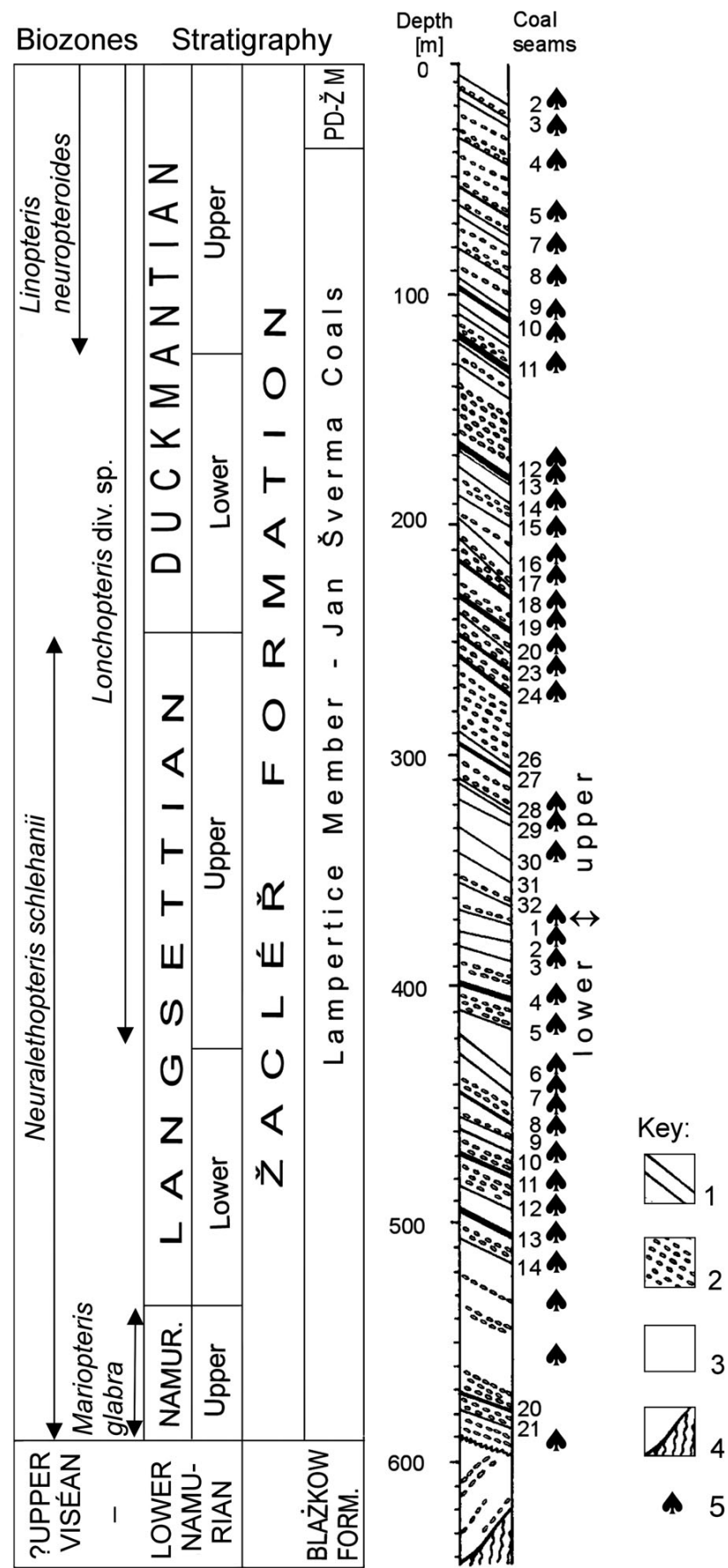

Figure 2. A simplified stratigraphic column of the Žaclér Formation in the pit Jan Šverma (crossed hammers near "Mine Jan Šverma" in Fig. 1). Key: 1 - coal seams, 2 - conglomerate, 3 - claystone, siltstone and sandstone, 4 - crystaline basement; 5 - occurrences of Paripteris gigantea according to Z. Rieger. Namur. - Namurian, PD-Ž M - Prkenný Důl-Žd’árky Member. (Lithology simplified according to Rieger et al. 1962, floral zones according to Purkyňová 1986.)

shown on each side of the "penultimate" rachis. Havlena (1953) noticed that there are in fact seven "ultimate" pinnae on the right side and six on the left side of the "penultimate" rachis. 
The "ultimate" pinnae are 170-180 mm long and 60-70 mm wide (see Fig. 3), and are elongatedly triangular. Their insertions on opposite sides are invariably shifted by 2-10 $\mathrm{mm}$. The pinnules grow close to each other or overlap by $1-2 \mathrm{~mm}$. They are attached almost opposite to each other or are mutually offset by $1-5 \mathrm{~mm}$. The pinnules are almost straight, tongue-shaped at the base of the "ultimate" pinnae. After 3-5 pairs they change into sickle-shaped arched pinnules with parallel margins. The sickle-shaped arching becomes more intense towards the apex of the "ultimate" pinna. The pinnules are 22-24 mm long and 8-9 mm wide in the middle of the pinna. The pinnules are concave on the basiscopic side and 40-45 lateral veins per $\mathrm{cm}$ occur along the margin, whereas only $36-40$ veins per $\mathrm{cm}$ of the margin occur on the acroscopic side. The flat midrib is visible to one-half of the pinnule lengths. The lateral veins are fine, several times forked, arching gently from the midrib and reach the pinnule margin at an angle of $50-70^{\circ}$.

The terminal pinnules are preserved only in two pinnae, but they are incomplete in one pinna. The complete terminal pinnules are unevenly developed, the larger pinnule being elliptic, $11.5 \mathrm{~mm}$ long and $4 \mathrm{~mm}$ wide, whilst the smaller pinnule is only $6.5 \mathrm{~mm}$ long and $3 \mathrm{~mm}$ wide. The intercalary pinnules are preserved only fragmentarily on the "penultimate" rachis. A very interesting feature is the bifurcating of the lowest left "ultimate" pinna (Fig. 3A, arrow). The two pinnules just above the bifurcation are small, rounded or suboval 6-7 $\mathrm{mm}$ in diameter. They are very similar to intercalary pinnules of other samples.

Emended diagnosis. - Pseudo-pinnate frond architecture, pinnules straight or sickle shaped, oblong-linear or ovallanceolate with slightly cordate base and obtuse to bluntly pointed apex. Midrib reaches up to 2/3 of the pinnule blade. Lateral veins very fine and dense, arising from the midrib at very sharp angles and dividing several times. Intercalary pinnules small orbicular, oval, rounded, triangular or tongue-shaped.

Adaxial cuticle is formed by oblong, tetragonal to hexagonal elongated cells. anticlinal cell walls of abaxial cuticle are slightly cutinised, stomata are sunken with papillate subsidiary cells. Pinnule margin with numerous trichome bases.

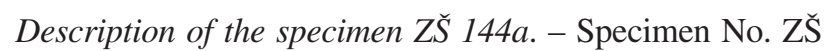
144 a represents fragments of two partly "ante-penultimate" pinnae (Figs 4, 5). The largest pinna has an "antepenultimate" rachis $700 \mathrm{~mm}$ long. It is around $5 \mathrm{~mm}$ wide along its entire length. It bears 11 or 12 "ultimate" pinnae on each side, even though they are not fully traceable due to preservation. The distance between rachises increases from 55 to $65 \mathrm{~mm}$ proximo-distally in the basal part of the pinna and from 48 to $55 \mathrm{~mm}$ in the terminal part of the pinna fragment. The pinnae are opposite or subopposite. The longest "ultimate" pinna is known from the basal acroscopic side $260 \mathrm{~mm}$, "ultimate" pinnae on the basiscopic side are up to
$240 \mathrm{~mm}$ long. Only a few pinnae are complete and terminated by two small pinnules (Fig. 8C, D). Two "ultimate" pinnae on the acroscopic side and one "ultimate" pinna on the basiscopic side show a single distal dichotomy (Figs 5, 6, $7 \mathrm{D}, 8 \mathrm{~A}, \mathrm{~B}$ ). This dichotomy can be equal (second proximal acroscopic pinna) or unequal. The bifurcation in this specimen starts 90 to $140 \mathrm{~mm}$ from the base of the rachis and the parts above the dichotomy are 130-180 mm long, respectively. The dichotomy angle is 45 to $60^{\circ}$. The remaining four proximal pinnae on the left (basiscopic) side of the specimen in Figs 5 and 6 show several anisotomous dichotomies on their basiscopic side only. The left side shows higher proximo-distal differentiation than the right side (Fig. 6).

The second fragment of the "penultimate" pinna is only $300 \mathrm{~mm}$ long. Six "ultimate" pinnae are preserved only on one (left) side in their incomplete length as the contact of both "penultimate" pinnae is somewhat obscure. The "ultimate" pinnae of the opposite side are turned down and hidden in the rock. The distances of "ultimate" pinnae increase proximo-distally and are from 45 to $52 \mathrm{~mm}$.

The "ultimate" pinnae are up to $260 \mathrm{~mm}$ long and $80 \mathrm{~mm}$ wide (in the middle). They taper slightly towards the base and apex.

Pinnules are very variable in shape and dimensions (Figs 7A, B, 8E, F). The "ordinary" pinnule shape is oblong-linear, or oval-lanceolate, perpendicular (in the basal and middle part of pinna) or slightly oblique (in the terminal part) to the rachis (Paripteris gigantea "forma typica", Fig 8F, or Paripteris gigantea "forma lingua" Fig. 7B). They can be sickle-shaped (mostly in the pinna terminal part) or straight (basal part), with a slightly cordate base. The "intercalated" pinnules are small orbicular, oval, rounded, triangular or tongue-shaped near the insertion (Fig. 8E); further on they are similar to the "normal" pinnules (Fig. 8E). The longest pinnule reaches $36 \mathrm{~mm}$, whereas the pinnules from smaller pinnae are only $25 \mathrm{~mm}$ in length. The width of pinnules is $8-12 \mathrm{~mm}$.

The venation is open, pinnate. The midrib is flat, traceable to half of the pinnule length (Fig. 8F). The lateral veins are fine, several times forked, and arise at a very sharp angle from the midrib. They bend and reach the pinnule margin at an angle of about $50-60^{\circ}$. The veins are relatively dense, 35-45 veins per $\mathrm{cm}$ on the pinnule margin.

Cuticles. - Cuticles (slides No. 158/1-2 and 476/1-10) were prepared from a specimen that originated from the borehole Š 13 (Žacléř locality), depth 489.85-490 m (between the $11^{\text {th }}$ and $10^{\text {th }}$ upper coal seams of the Šverma mine, Fig. 7C).

Pinnule adaxial epidermis (Fig. 9A, D): Costal and intercostal fields are weakly differentiated. Intercostal cells (Fig. 8A, B) are longitudinally tetragonal (oblong or trapezoidal), 60-120 $\mu \mathrm{m}$ long and 12-20 $\mu \mathrm{m}$ wide, with straight to slightly bent anticlinal cells and parallel to the veins. 




Figure 3. Paripteris gigantea (Sternberg) Gothan. Holotype, Sternberg (1821, pl. 32), Žaclér locality. National Museum, Prague, No. E $4672 . \times 0.5$.

Shape and size of the costal cells are the same as in the intercostal ones. Only the adaxial cuticle of the midrib differs (Fig. 9D). The cells are oriented parallel to the midrib, and are square to oblong, 30-50 $\mu \mathrm{m}$ long and 25-40 $\mu \mathrm{m}$ wide.

Pinnule margin epidermis (Fig. 9E-H): The cells differ from cells of the adaxial and abaxial epidermis by being strongly cutinised and also by their shape. The band of these cells is $200-300 \mu \mathrm{m}$ wide. The cells are elongated, oblong, tetragonal or trapezoidal. The anticlinal walls are prominent, straight, or only slightly bent. The cells are 30-70 $\mu \mathrm{m}$ long and 10-20 $\mu \mathrm{m}$ wide. The structural holes occur relatively densely among these cells. They are relatively small, circular to oval, 20-25 $\mu \mathrm{m}$ in diameter (Fig. 9E-H). Their function is not certain, but most probably they are trichome bases, where trichome remnants, such as cutinised collars, were not preserved. Trichomes were probably actively abscissed from the plant during life at the cuticle surface, which would mean that no cutinised collar was left. The trichome base density varies from place to place, but it is usually within 120-200 trichome bases per $\mathrm{mm}^{2}$.

Pinnule abaxial epidermis (Figs 9B, C, 10A-C): The anticlinal walls and cell outlines are very weak and therefore it is difficult to trace any difference between costal and intercostals fields. The intercostal cells are polygonal, partly elongated, with straight to slightly curved anticlinal walls. The cells (Fig. 10A, B) are 22-35 $\mu \mathrm{m}$ long and 16-20 $\mu \mathrm{m}$ wide. Monocyclic stomata (Figs 9B, C, 10B, C) occur in the intercostal field. Pairs of guard cells, 22-30 $\mu \mathrm{m}$ long and 10-14 $\mu \mathrm{m}$ wide, are elliptical, sunken and partly covered by proximal papillae of the subsidiary cells (Figs 9B, C, 10C), and orientated parallel to the veins. The subsidiary cells are polygonal to trapezoidal, five to six in number around each stoma. The anticlinal walls are only partly visible. The estimated stomatal density is 220-260 stomata per $\mathrm{mm}^{2}$ and the stomatal index is approximately 10. There are circular or oval structures in the costal field of the abaxial cuticle, which are $25-35 \mu \mathrm{m}$ in diameter. Some 


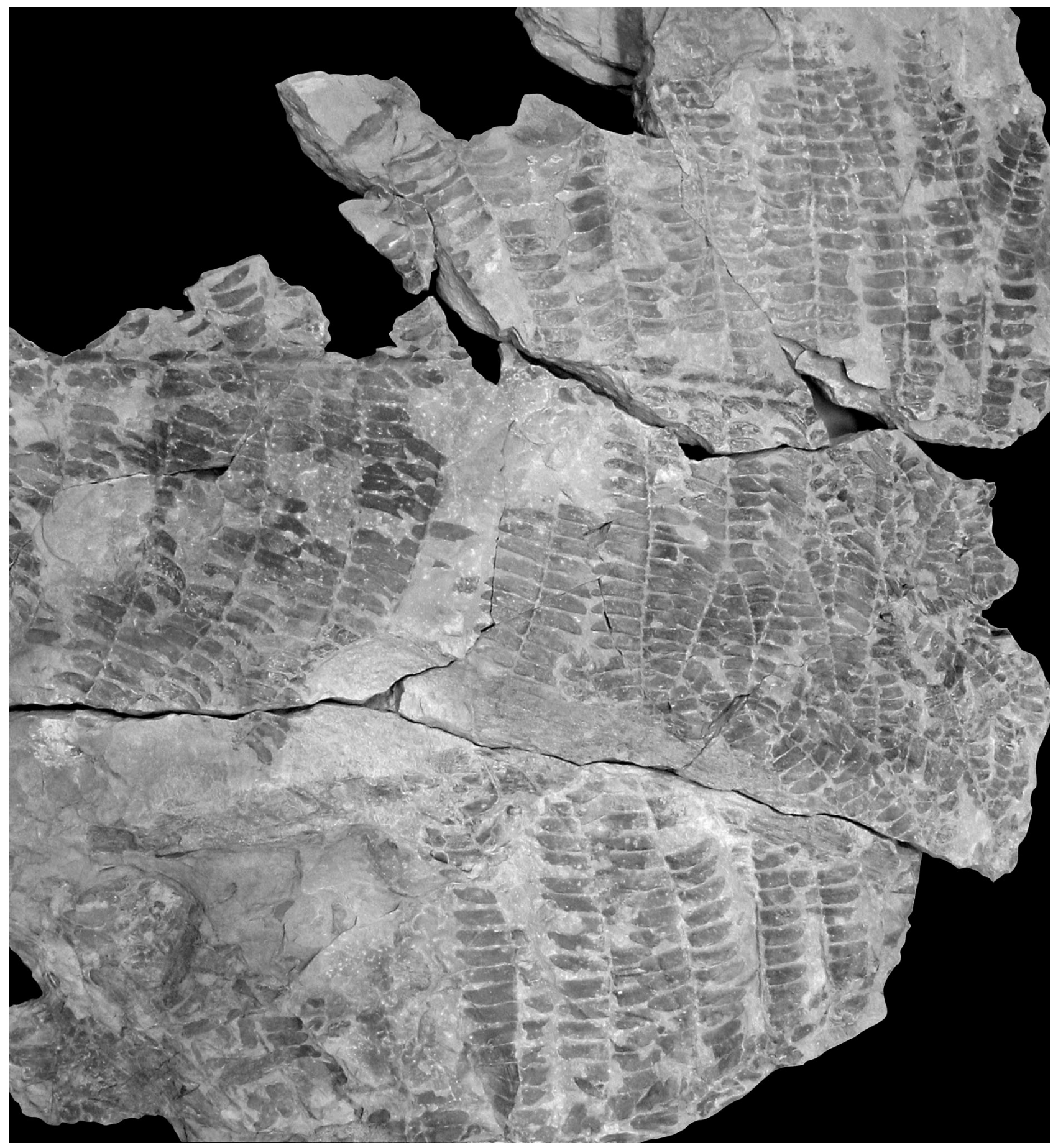

Figure 4. Paripteris gigantea (Sternberg) Gothan, Žaclér, Quarry 4, roof of the $9^{\text {th }}$ upper coal seam, Duckmantian. Czech Geological Survey, Prague, No. ZŠ 144 (1-4). Fragments of a partly "ante-penultimate" and two partly "penultimate" pinnae, $\times 0.25$.

of the cells have a smaller circular to oval hole in the middle (Fig. 10C). They are probably trichome bases. The density of trichome bases is $8-16$ per $\mathrm{mm}^{2}$.

Cuticles of the species Paripteris gigantea have already been studied by Barthel (1961), from a specimen from the Langsettian (Westphalian A) of the Upper
Silesian Basin. Barthel (1961) described adaxial cuticles with putative papillae on the cells (his fig. 5); however, he figured only a small fragment (his pl. 3, fig. 9). Papillae are not visible there. Moreover, it seems that this cuticle is from the midrib, because the cells are relatively wide and resemble the midrib cuticle described here (Fig. 9D). 
Barthel (1961) in fact did not figure any intercostal field of an adaxial cuticle. Barthel (1961) described and figured a "papilla" on an adaxial cuticle on his pl. 3, fig. 8. The cuticular specimen from Žacléř possesses similar structures in the costal fields of the abaxial cuticle and in the location of the midrib (Fig. 10B, C). These structures were classified as trichome bases. Barthel (1961) mentioned papillary subsidiary cells of stomata on the abaxial cuticle. The same papillae also occur in the Žaclér specimen. The only difference is in the dimensions of the guard cells. Barthel (1961) mentioned 15-20 $\mu \mathrm{m}$ long and 12-15 $\mu \mathrm{m}$ wide pairs of guard cells from the Upper Silesian specimen, whereas the pairs of guard cells from the Žaclér sample are 22-30 $\mu \mathrm{m}$ long and 10-14 $\mu \mathrm{m}$ wide. The presence of the same type of trichome bases and papillary stomata, and the same pattern of abaxial cuticle cells shows that Barthel's (1961) and these specimens belong to the same species, Paripteris gigantea.

The cuticles of other "Paripteris" species have not been studied yet in detail. Cuticles of the related "species" Paripteris linguaefolia P. Bertrand from Central Bohemia near Rakovník were studied by Šimůnek (2007). Its adaxial cuticle is not preserved. Abaxial cuticles of Paripteris linguaefolia also have very slightly prominent anticlinal walls; the stomata are deeply sunken and covered by the proximal papillae of the subsidiary cells (Šimůnek 2007). This feature is not so strongly developed in Paripteris gigantea.

\section{Discussion}

The taxonomy of the genus Paripteris Gothan, 1941 is still not satisfactorily solved. Gothan (1941) placed in his genus Paripteris the following species: Paripteris gigantea (Sternberg, 1821) Gothan, 1941, P. pseudogigantea (Potonié, 1897) Gothan, 1941 and P. lunata White, 1900. Daber (1963) transferred Neuropteris schuetzei Potonié, 1903 to Paripteris. Laveine $(1967,1971)$ classified the species Neuropteris linguaefolia Bertrand, 1930 and Neuropteris linguaenova Bertrand, 1930 also as Paripteris. Moreover, many forms and varieties of $P$. gigantea have been described when it was still placed in Neuropteris: $N$. gigantea forma typica, N. gigantea var. abbreviata Stockmans, 1933, N. gigantea forma arcuata Novik, 1952, N. gigantea forma lingua Novik, 1952, and N. gigantea forma triangularis Bertrand, 1930. Havlena (1953) came to the conclusion that up to three forms can occur in one frond of Paripteris gigantea - formas typica, triangularis and lingua. Crookall (1959) included practically all Paripteris species in the species "Neuropteris" gigantea as is evident from his synonymy and remarks. Since that time the name Paripteris has become more common and the species Paripteris gigantea, P. pseudogigantea and $P$. linguaefolia have become the most used names in the European literature (e.g., Laveine 1967, 1971; Josten 1991). In the $20^{\text {th }}$ century,

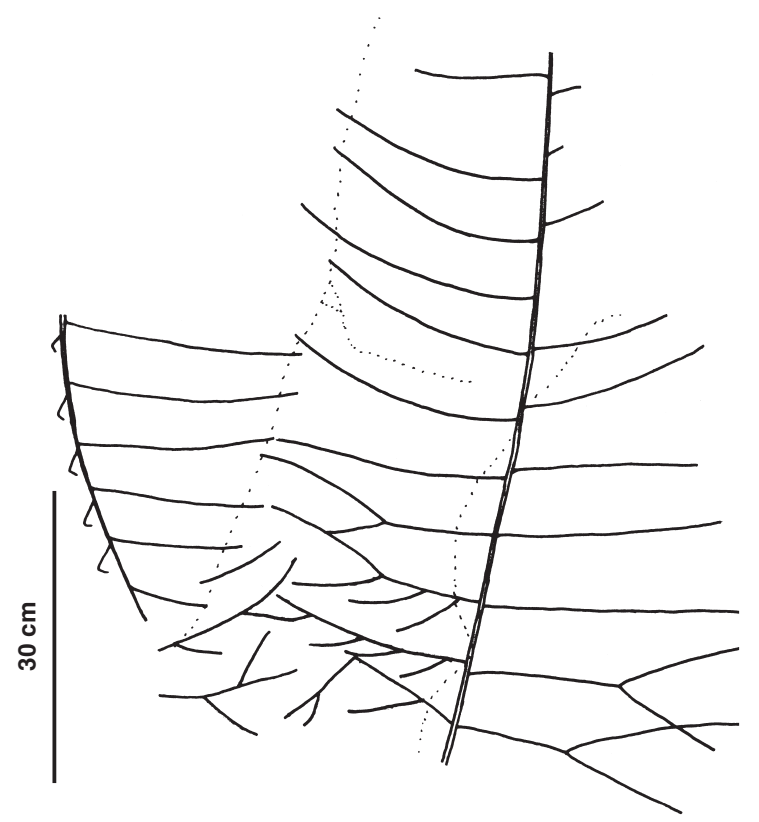

Figure 5. Drawing of "ultimate" and "ante-penultimate" rachises of Paripteris gigantea (Sternberg) Gothan, according to fragment figured in Fig. 4. Note the dichotomy of some "ultimate" pinnae.

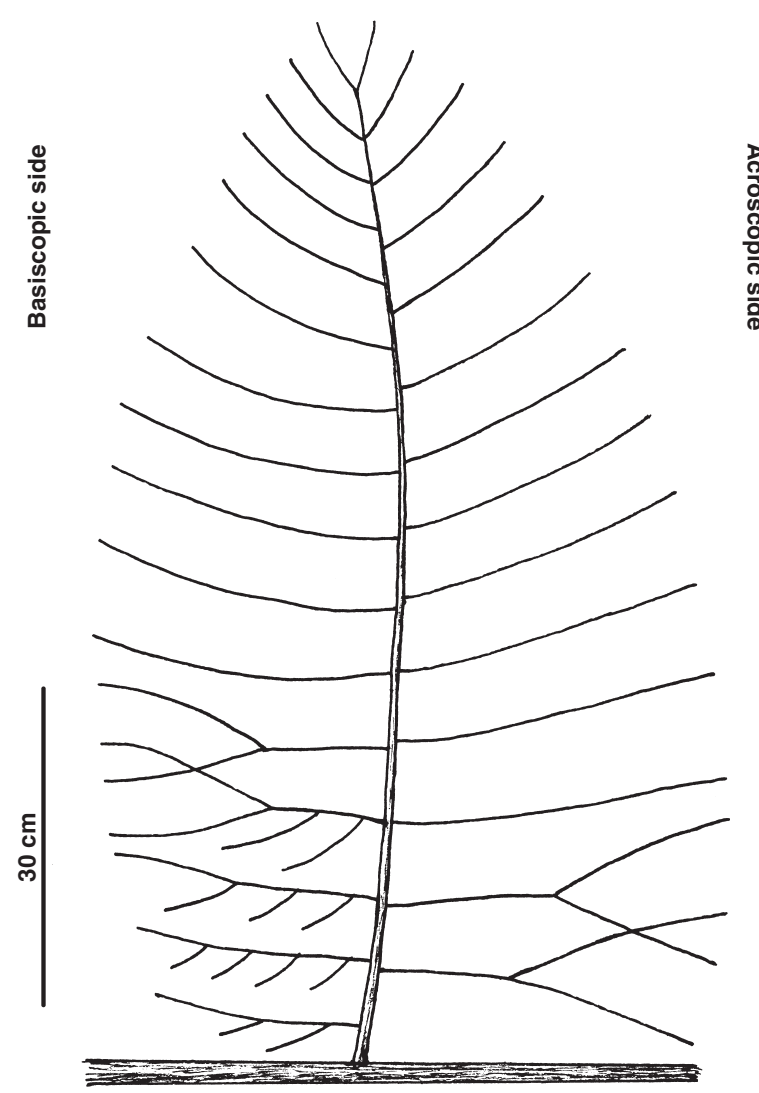

Figure 6. Reconstruction of about $1 \mathrm{~m}$ long partly "ante-penultimate" pinna from the central part of an "ante-ante-penultimate" frond. The basal basiscopic pinnae show anisotomous dichotomies on their basiscopic surface (see Laveine et al. 1993, text-fig. 9). Two basal acroscopic pinnae show single distal dichotomy. 

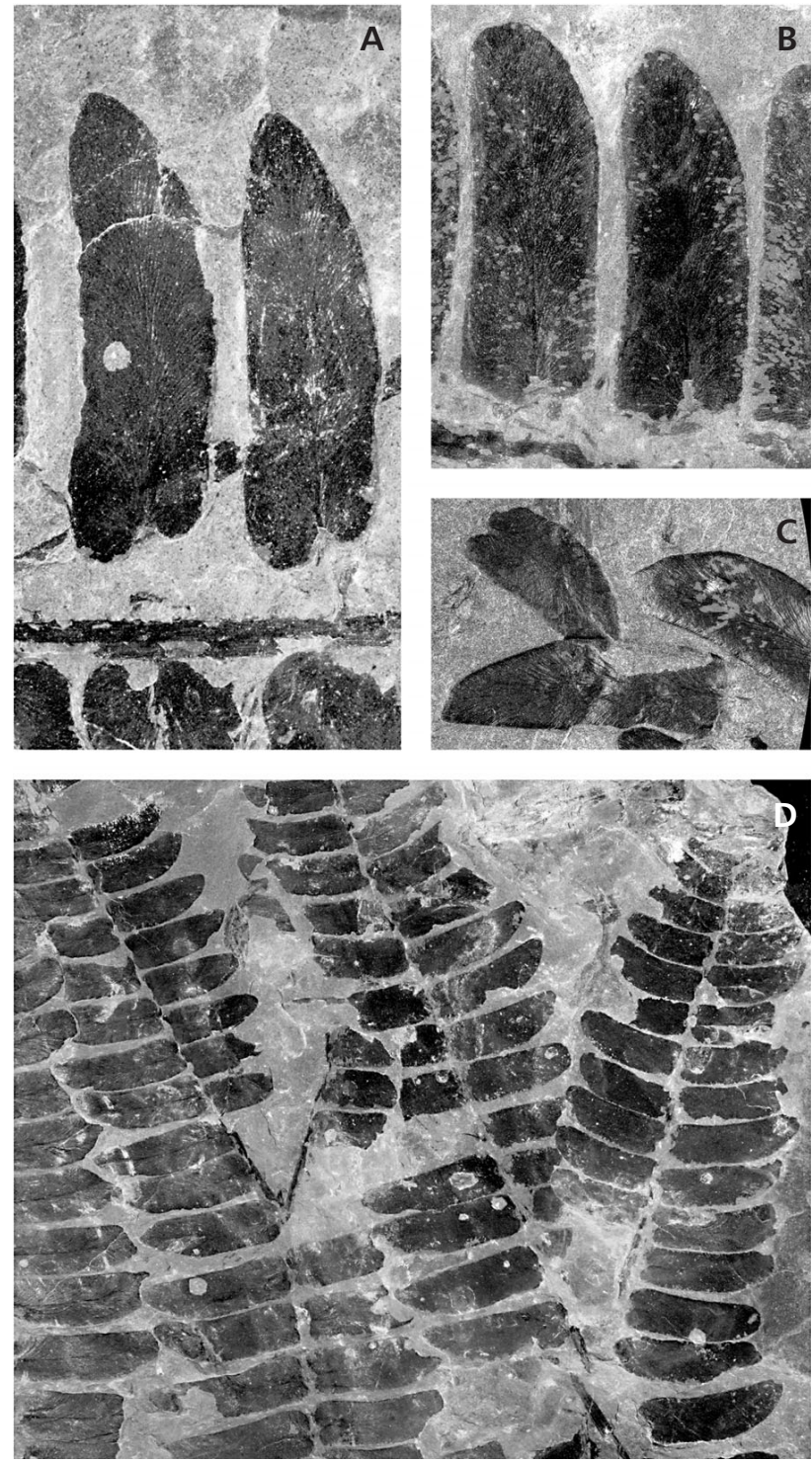

Figure 7. Paripteris gigantea (Sternberg) Gothan, Žaclér, Quarry 4, roof of the $9^{\text {th }}$ upper coal seam, Duckmantian. $\bullet A, B$ - details of pinnules (B - "forma lingua Betrand"), $\times 1.5$. • C - isolated pinnules - material for cuticles in Figs 9, 10. Loc. Lampertice near Žacléř, borehole S 13, depth 489.85-490 m, 10 ${ }^{\text {th }}$ overlying seam of the Šverma Mine Coals. Coll. Z. Rieger, Czech Geological Survey, Prague, No. ZŠ 19, × 1. • D - detail of frond showing bifurcated "unipinate" pinnae, $\times 0.5$.

many specimens belonging to Paripteris were described from Asia as species of the genus Neuropteris Brongniart: Zhang et al. (1993) concluded that Neuropteris kaipingiana Sze, 1930, N. otozamioides Sze \& Lee, 1946 and "N." cardiopteroides Bohlin, 1971 from Asia belong to the genus Paripteris. It must be noted that "Neuropteris" cardiopteroides Bohlin, 1971 is a younger homonym of Neuropteris cardiopteroides Schmalhausen, 1879. Zhang et al. (1993) faced the great variability of paripterid pinnules from China: lingular, subtriangular, triangular pinnules with a straight, subfalcate or falcate outline. Because they found transitions among these morphotypes, they provisionally considered all these pinnules as belonging to one species - Paripteris gigantea (Sternberg) Gothan with many forms that reflect the variability of the pinnules: $P$. gigantea f. gigantea, P. gigantea f. lunata (White) Zhang et al., $P$. gigantea $\mathrm{f}$. kaipingiana (Sze) Zhang et al., $P$. gigantea f. abbreviata (Stockmans) Zhang et al., $P$. gigantea f. linguaefolia (Bertrand) Zhang et al., P. gigantea f. pseudogigantea (Potonié) Zhang et al., P. gigantea f. cardiopteroides (Bohlin) Zhang et al., $P$. gigantea f. otozamioides (Sze \& Lee) Zhang et al. and the new formae $P$. gigantea f. acuminatissima and $P$. gigantea $\mathrm{f}$. longifolia. The same trinomial concept was used in Laveine et al. (2003).

Laveine et al. (1993) emphasized that the genus Paripteris had the greatest variability in China during the late Viséan and early Namurian. According to Laveine et al. (1993), it is the time when this genus originated and reached the greatest diversity and disparity, but later selection pressure caused diminished diversity. For example, acuminate forms known from the lower Namurian of China do not occur in the middle and upper Namurian of Europe. Moreover, Laveine et al. (1993) found a large frond with pinnules similar to the typical Paripteris gigantea in one part and pinnules similar to Paripteris pseudogigantea in another part of the frond. Laveine et al. (1993) concluded that the local Spanish species, Paripteris asturiana (Jongmans) Wagner, 1962, also belonged to Paripteris pseudogigantea, the only difference is that Paripteris asturiana has pinnules of about a half the size of those of Paripteris pseudogigantea. Laveine et al. (1993) are of the opinion that Paripteris asturiana is an ecoform or geographically restricted form. Only the following forms of Paripteris gigantea introduced by Zhang et al. (1993) were recognized in Europe: $P$. gigantea f. gigantea, $P$. gigantea f. abbreviata, $P$. gigantea f. linguaefolia and $P$. gigantea $\mathrm{f}$. pseudogigantea. The forms $P$. gigantea $\mathrm{f}$. linguaefolia and $P$. gigantea f. pseudogigantea were originally described as species of the genus Neuropteris Brongniart and are characterized by morphological features of the pinnules (Table 1). Individual forms also have different stratigraphical ranges. The forms $P$. gigantea gigantea and $P$. gigantea abbreviata occur in the Namurian and Lower Westphalian and the forms $P$. gigantea linguaefolia and P. gigantea pseudogigantea usually occur first in the Westphalian and the last record of these forms is before it ends. In particular, $P$. gigantea $\mathrm{f}$. linguaefolia is important for Bolsovian (Westphalian C) floras. Wagner (1984) considers this "forma" as the index species of the Paripteris linguaefolia Zone. However, Brousmiche Delcambre et al. (1996) found this "species" together with Neuralethoptreis schlehanii (Stur) Cremer in the Namurian strata of Briançonais (France). They used the trinomial system of classificationParipteris gigantea (Sternberg) forma linguaefolia (Bertrand) Zhang et al. 

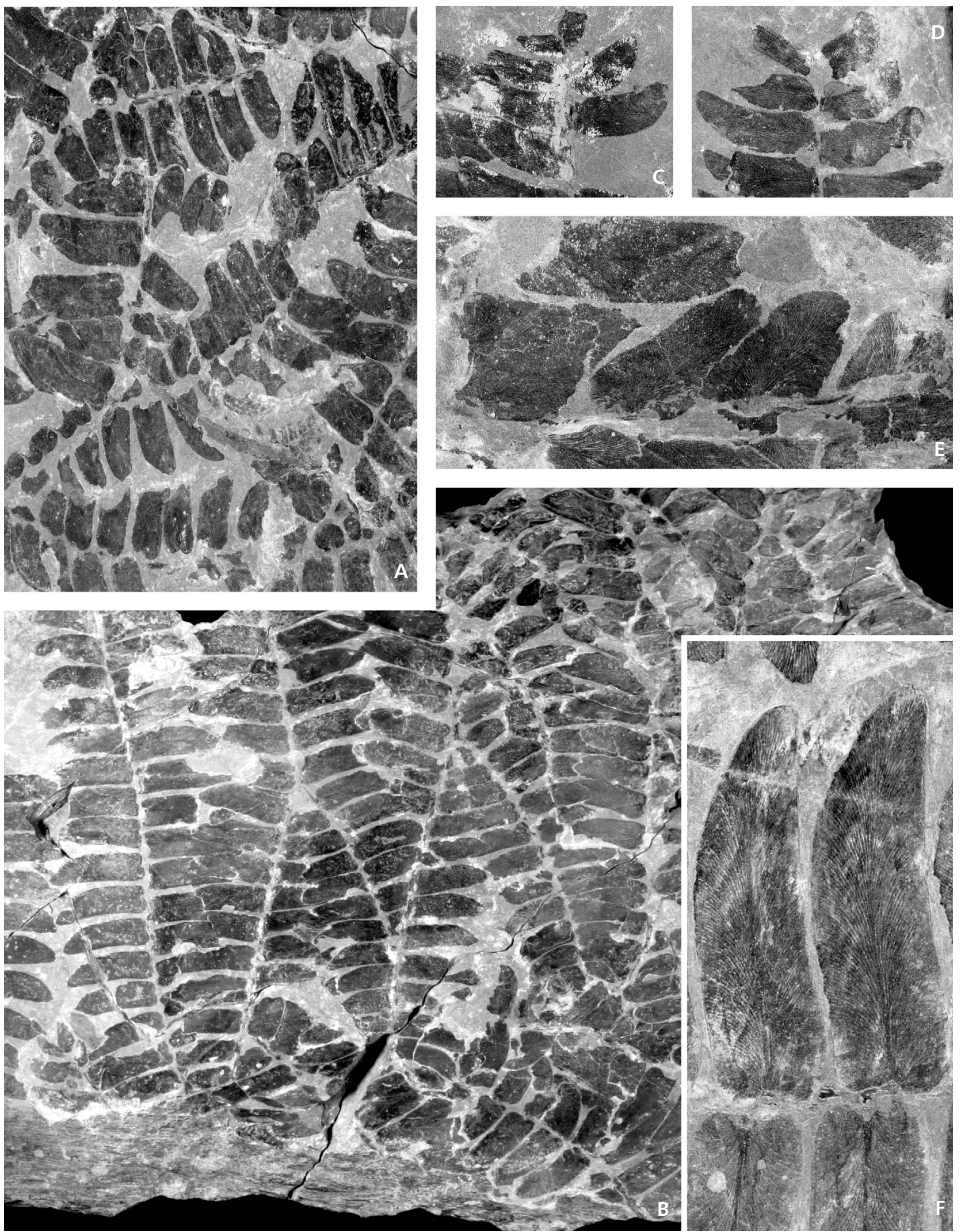

Figure 8. Paripteris gigantea (Sternberg) Gothan, Žaclér, Quarry 4, roof of the $9^{\text {th }}$ upper coal seam, Duckmantian. $\bullet$ A - fragments of repeatedly bifurcating pinnae from Fig. $8 \mathrm{~B}, \times 0.7$. $\bullet \mathrm{B}-$ fragment of "penultimate" pinna showing bifurcated "ultimate" pinnae, $\times 0.5 . \bullet \mathrm{C}, \mathrm{D}-$ terminal parts of pinnae with pairs of apical pinnules, $\times 1 . \bullet \mathrm{E}-$ rachis with "intercalated" pinnules, $\times 1.5$. $\bullet \mathrm{F}-$ detail of two "normal" pinnules (forma typica),$\times 2$. 
Table 1. Comparison pinnule morphology of three Paripteris "species". According to Josten (1991) and the author's observation. 1 - pinnule length $[\mathrm{mm}], 2$ - pinnule width $[\mathrm{mm}], 3$ - midrib, 4 - vein density, 5 - form of pinnule

\begin{tabular}{llll}
\hline & P. gigantea & P.pseudogigantea & P. linguaefolia \\
\hline 1 & $25-40$ & $<20$ & $30-45$ \\
2 & $10-15$ & 5 & $10-20$ \\
3 & up to $1 / 2$ of the pinnule & up to $4 / 5$ of the pinnule & $\begin{array}{l}\text { without or only } \\
1-2 \mathrm{~mm}\end{array}$ \\
& & & $30-35$ per cm \\
5 & 35-50 veins per cm & cca 30 per cm & tongue-shaped \\
& tongue-shaped & tongue-shaped & \\
\hline
\end{tabular}

The situation in the Bohemian part of the Intrasudetic Basin is not so complicated, as in the Žaclér area only one species of Paripteris - Paripteris gigantea - is known. According to Havlena (1953), it is possible to distinguish three forms of this species, viz. typica, triangularis and lingua. Pinnules of all these forms can be found in a single pinna, and therefore these forms have no taxonomic significance. Zhang et al. (1993) did not consider these "forms" in their taxonomy. The age of these samples ranges from late Namurian to early Duckmantian. However, Havlena (1953) found both "species" or "forms" $P$. (gigantea f.) gigantea and $P$. (gigantea f.) linguaefolia at several localities (Markoušovice, Žd'árky u Hronova) of late Duckmantian age. He explained this situation with partial overlap of the species "Paripteris gigantea", which was approaching extinction at that time, and "Paripteris linguaefolia" which originated not long before. The difference between these species is mainly in the length of midrib (Table 1). "Paripteris linguaefolia" is without a midrib, or with only a very short one, "Paripteris gigantea" should have the midrib at least to $1 / 2$ of the pinnule blade. Havlena (1953) classified the isolated pinnules with a longer midrib as Neuropteris gigantea. It seems that there also exists variation in the length of the midrib. The presence of Paripteris pseudogigantea in the Intrasudetic Basin has not been recorded.

Now we return back to our sample. Its left side shows a higher proximo-distal differentiation than the right side (Fig. 6), and therefore must be basiscopic. The penultimate rachis is slightly bent to the base of the frond. The correct position of this pinna within the frond is not known. Either it represents a lateral, not very differentiated pinna from the basal part of a small frond, in which the basal lateral fronds were bent basally, or, more probably, it represents a lateral, partly "penultimate" pinna from the terminal (distal) part of the frond (see Laveine et al. 1993, fig. 11). The slightly proximally turned rachis can be explained by taphonomy. Laveine at al. (1993, fig. 11) showed a reconstruction of a frond up to $6 \mathrm{~m}$ long and $4 \mathrm{~m}$ wide. The "lateral" pinnae with a similar segmentation as in Laveine's reconstruction are less than $1 \mathrm{~m}$ long. The described pinna must have been more than $1 \mathrm{~m}$ long. Laveine's pinnae do not show such a distal dichotomy of the "ultimate" pinnae as in the sample described here. Nevertheless, this specimen can be fitted into Laveine's et al. (1993) reconstruction.

Cleal \& Shute (1995) followed the traditional binomial classification and used the following Paripteris species names: $P$. gigantea (Sternberg) Gothan, P. linguaefolia (Bertrand) Laveine, $P$. linguaenova (Bertrand) Cleal \& Shute, P. pseudogigantea (Potonié) Gothan and $P$. schuetzei (Potonié) Daber.

It is difficult to decide which concept is better. If we have typical samples, we can distinguish the above mentioned "species". However, there are localities, where large pinnule variability can be seen and more Paripteris "species" seem to be present in a single locality. It is really unusual that several related species can occur together, which tends to fit in better with Laveine's et al. (1993) concept.

The adaxial cuticle of Paripteris gigantea has oblong, tetragonal to hexagonal elongated cells and thus resembles some neuropterid species: Neuropteris neuropteroides, Neuropteris tennuifolia and Neuropteris obliqua (Barthel 1962), Neuropteris scheuchzeri (Barthel 1961, Cleal \& Zodrow 1989), Neuropteris rarinervis Bunbury, N. flexuosa (Cleal \& Zodrow 1989) and Neuropteris terminiscus (Cleal 2002). Of course, cuticles of individual species differ slightly in shape and dimension of cells.

The abaxial cuticle of Paripteris gigantea is typified by slightly cutinised anticlinal cell walls and sunken stomata with papillate subsidiary cells. Such cuticles can be observed in some linopterids: Linopteris weigelii and L. neuropteroides and neuropterids: Neuroteris obliqua and Neuropteris tennuifolia (Barthel 1961), Laveineopteris loshii (Cleal \& Shute 1992) and L. rarinervis (Cleal \& Zodrow 1989).

However, the typical feature of Paripteris gigantea cuticles is a more cutinised rim at the pinnule margin with numerous trichome bases. Such a feature has not been observed in any other medullosan species and neither in Paripteris linguaefolia (Šimůnek 2007). A comparison of these two species is not possible because the cuticles of Paripteris linguaefolia are poorly preserved. Further observation of other Paripteris linguaefolia cuticles are required for a detailed comparative analysis.

\section{Paleoecology}

Paripteris gigantea (Sternberg) Gothan, is the most common species in the Žaclér Formation of the Žacléř area. It was found by Rieger et al. (1962) associated with nearly all coal seams there, mostly in roof rocks (Fig. 2). It is also the dominant species in many of the studied quarries (Fig. 1). However, large frond fragments are very rare, and the described specimen is exceptional, even when compared to 

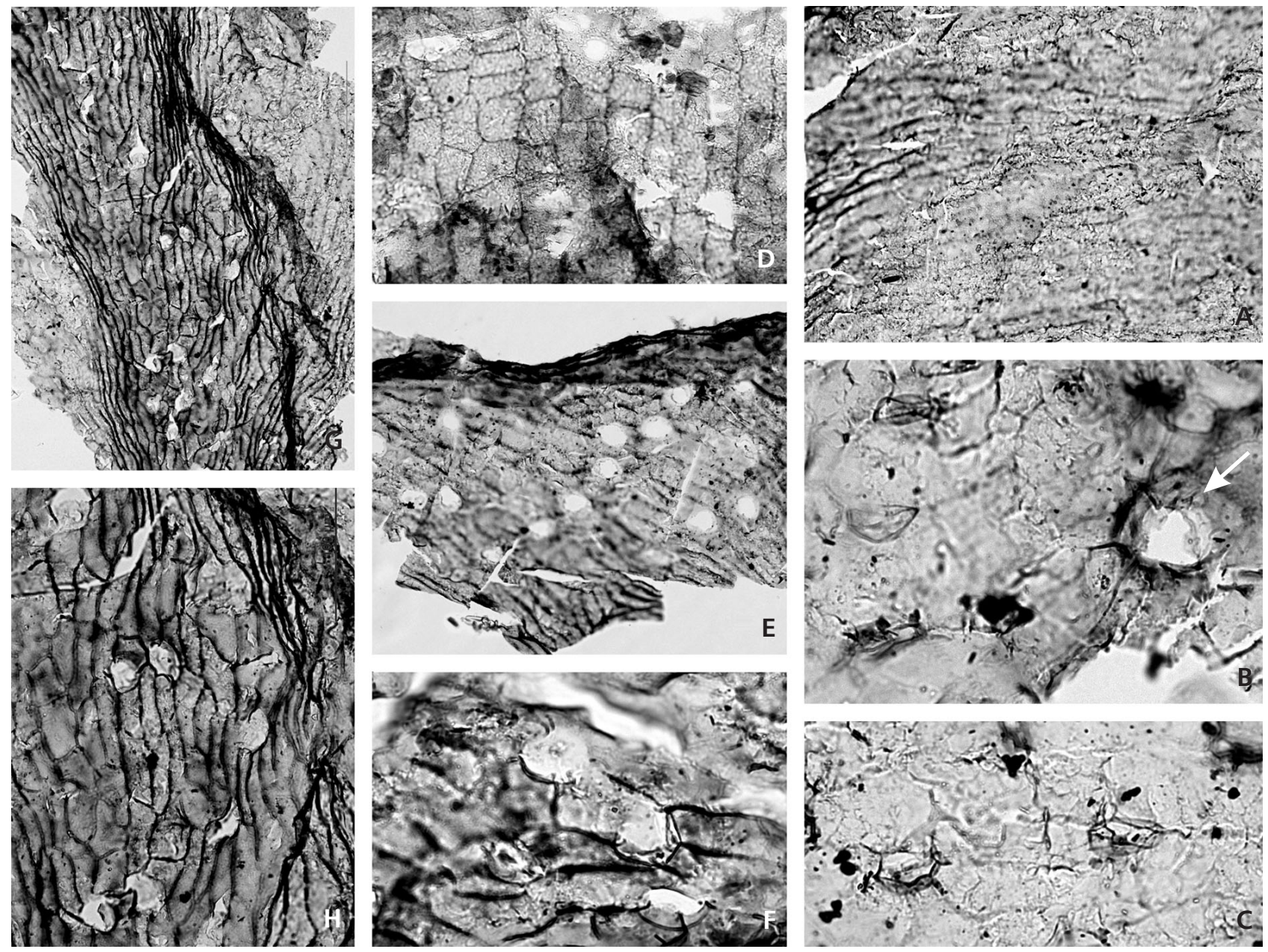

Figure 9. Paripteris gigantea (Sternberg) Gothan, Lampertice near Žacléř, borehole Š 13 , depth $489.85-490 \mathrm{~m}$. $10^{\text {th }}$ overlying seam of the Šverma mine, Lampertice Member, Duckmatian. (Specimen on Fig. 7C.) $\bullet$ A - adaxial cuticle. Slide 476/8, $\times 200$. B - a detail from Fig. 10A with a trichome base (arrow) and 3 stomata, $\times 500 . \bullet \mathrm{C}$ - abaxial cuticle in the intercostal field with two stomata. Slide $476 / 5, \times 500 . \bullet \mathrm{D}$ - adaxial cuticle in the place of midrib. Slide $158 / 1, \times 200 . \bullet$ E - pinnule margin with trichome bases. Slide $476 / 6, \times 200$. $\bullet$ - detail of trichome bases. Slide $476 / 8, \times 500$. $\bullet$ G - pinnule margin with trichome bases. Adaxial cuticle is in the upper right corner, abaxial cuticle is in the lower left corner. Slide $476 / 10, \times 150$. $\bullet \mathrm{H}-$ detail of trichome bases from Fig. 9G, × 300 .

Laveine's specimens (Laveine 1967, pls 70-72). Paripteris gigantea obviously had few ecological demands, because it spread throughout Europe very quickly after overcoming the barrier between Asia and Europe during the Kinderscoutian and Marsdenian (Namurian B) (Laveine et al. 1993). The presence of isolated pinnules in different types of sediment can be explained by primarily large fronds, up to $6 \mathrm{~m}$ long (Laveine et al. 1993), bearing many pinnules with a constricted cordate base, that could be easily abscised. Cleal \& Laveine (1988) described juvenile fronds of Paripteris gigantea with partly preserved pinnules on a petiole, but pinnules from the petiole had abscised already even in the juvenile stage of the frond. Probably, when the mature fronds died, they disintegrated very quickly into rachises and individual pinnules; the latter could be transported through wind and water very easily (Wnuk \& Pfefferkorn 1984).
Riverbanks were probably the natural habitat of Paripteris gigantea (Sternberg) Gothan. Vegetation of riverbanks grew on elevated (levee), well-drained substrates with a high nutrient level supply. These substrates were inundated only during floods and the presence of some tree or liana-like pteridosperms is a typical feature (Iwaniw 1985). The most common are fragments of fronds of Mariopteris muricata (Schlotheim) Zeiller and isolated pinnules of Paripteris gigantea concentrated on bedding surfaces in association with trigonocarpid seeds (Libertín et al. 2009). Less common species in this community are: Alethopteris valida Boulay, Linopteris neuropteroides Gutbier f. major Potonié, Lonchopteris rugosa Brongniart, Pecopteris plumosa (Artis) Brongniart, Annularia radiata (Brongniart) Sternberg, Palmatopteris furcata (Brongniart) Potonié, Sphenophyllum cuneifolium (Sternberg) Zeiller, Trigonocarpus noeggerathii Sternberg and Calamites (Diplocalamites) carinatus Sternberg. 

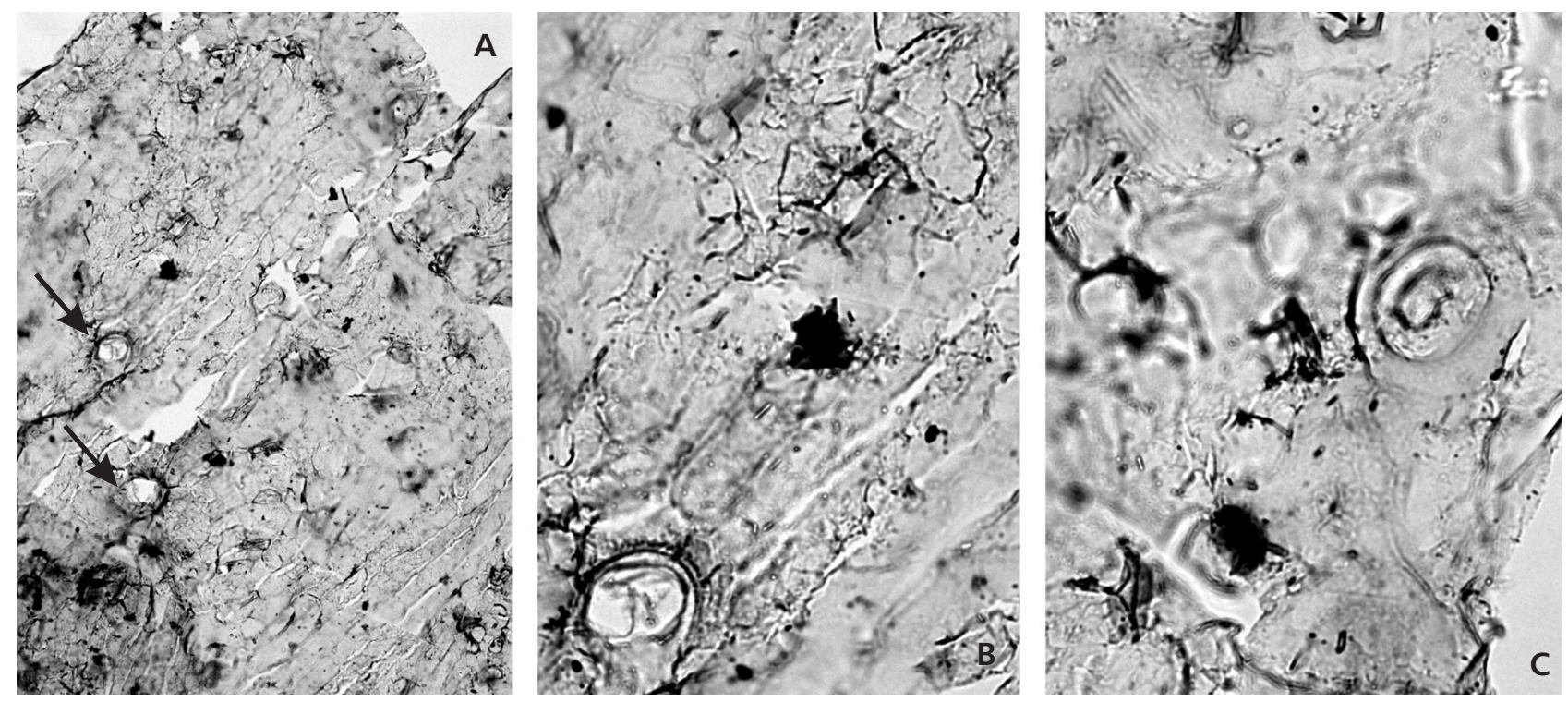

Figure 10. A - abaxial cuticle with two trichome bases (arrows) and alternating costal fields and intercostal fields with stomata. Slide $476 / 5, \times 150$. $\bullet$ B - abaxial cuticle with a trichome base and a stoma from Fig. $10 \mathrm{~A}, \times 500 . \bullet \mathrm{D}-$ a detail of abaxial cuticle with a trichome base and stomata. Slide $476 / 9, \times 500$.

Paripteris gigantea (Sternberg) Gothan was also an important element of the plant assemblage growing on well-drained substrates. Pteridosperms, some ferns and calamites are typical for well-drained substrates in the Žaclér locality. Sphenophytes are represented especially by the genera Calamites Brongniart and Sphenophyllum Brongniart, which occur as pioneer vegetation in places with an unstable substrate (Behrensmeyer et al. 1992). Dominant species here are Pecopteris plumosa (Artis) Stur, a lianescent fern, and the already mentioned medullosan pteridosperm Paripteris gigantea, which preferred well-drained nutrient-rich substrates. Neuropteris obliqua (Brongniart) Zeiller also had similar ecological demands. Cordaitaleans grew on both well-drained and poorly drained substrates probably due to their physiological xeromorphism (Wardtmann 1969). The recently described species Cordaites schatzlarensis Šimůnek \& Libertín, 2006 with about $50 \mathrm{~cm}$ long leaves is associated with seeds of Samaropsis newberryi (Andrews) Seward.

Other elements of this assemblage are Palmatopteris furcata (Brongniart) Potonié, Annularia radiata (Brongniart) Sternberg, Eusphenopteris obtusiloba (Brongniart) Novik, Calamostachys intermedia Němejc and Calamites (Diplocalamites) carinatus Sternberg.

Based on previous studies and on new data from opencast mines in the Žaclér area, it is possible to interpret sediments of the Lampertice Member as the fill of a tectonically controlled system of piedmont river valleys, drained generally to the NE (Libertín et al. 2009). These valleys were occupied by a fluvial system, which is interpreted as a low-sinuosity braided river and wandering gravel-bed river (Miall 1985). This fluvial style is characterized by the well-developed floodplain with clastic to peat swamps.

\section{Taphonomy}

Three plant associations, autochthonous, parautochthonous and allochthonous were recognized, based on taphonomic research of the assemblage of plants from one lithofacies. However, only two species of pteridosperms - Paripteris gigantea (Sternberg) Gothan and Mariopteris muricata (Schlotheim) Zeiller were more tolerant to different ecological conditions and occur in most of the studied taphocenoses. This is in accordance with DiMichele et al. (2006) who stated that most early and middle Pennsylvanian arborescent medullosan species lived in clastic floodplain environments, but only a few could tolerate areas of long-persistent standing water.

\section{Conclusions}

Newly prepared cuticles of Paripteris gigantea from the type area resemble the cuticles prepared by Barthel (1961) from a specimen from the Upper Silesian Basin. The structures he described as epidermal papillae are interpreted here as trichome bases. New information on the cells and trichome bases on the pinnule rim of Paripteris gigantea is given. This plant grew in different habitats, ranging from well-drained substrates to clastic floodplain environments with short-term standing water. Up to now, very little information is known about the epidermal structures of other species of the genus Paripteris.

To date, two different concepts of classification of the genus Paripteris Gothan are used: 1. The trinomial classification of Zhang et al. (1993) that accommodates all the so-far recognized paripterid species as forms of the species Paripteris gigantea. This classification reflects morpho- 
logical differences (variability or polymorphism) that sometimes prevent distinguishing individual species and formae, therefore all species are formae in this classification. 2. The traditional binomial classification (e.g., Josten 1991, Cleal \& Shute 1995) leaves the taxonomic entities at their original value - species. This paper does not deal with this problem. Maybe cuticular analysis of other paripterid species and forms will help to solve this problem in the future.

\section{Acknowledgements}

This research was funded by the Grant Agency of the Academy of Sciences of the Czech Republic, Grant A3013306 and the Grant Agency of the Czech Republic, Grant 205/05/2034. In the first place, the author thanks his colleagues M. Libertín and R. Labuta from the National Museum in Prague (Czech Republic) for their help in field work, J.P. Laveine from the Museum in Lille (France) for useful comments on the text. The author thanks C.J. Cleal from the National Museums and Galeries of Wales in Cardiff (Great Britain) for correcting the English, and also two reviewers H. Kerp from Münster (Germany) and E. Zodrow, Sydney (Canada).

\section{References}

ARNOLD, C.A. 1941. Some Paleozoic plants from Cental Colorado and their stratigraphic significance. Contributions from the $\mathrm{Mu}$ seum of Paleontology, The University of Michigan 6(4), 59-70.

BARTHEL, M. 1961. Der Epidermisbau einiger oberkarbonischer Pteridospermen. Geologie (Berlin) 10, 828-849.

BARTHEL, M. 1962. Epidermisuntersuchungen an einigen inkohlten Pteridospermenblättern des Oberkarbons und Perms. Geologie (Berlin) 11(33), 1-140.

BeHRENSMEYER, A.K., DAMUTH, J.D., DiMiChELE, W.A., POTTS, R., SUES, H.-D. \& WING, S.L. 1992. Terrestrial ecosystems through time. Evolutionary Paleoecology of Terrestrial Plants and Animals. 568 pp. The University of Chicago Press, Chicago \& London.

BELL, W.A. 1944. Carboniferous rocks and fossil flora of Northern Nova Scotia. Memoirs of the Geological Survey of Canada 238, $1-276$.

BERTRAND, P. 1930. Bassin houiller de la Sarre et de la Lorraine. Études des gîtes minéraux de la France. I. Flore Fossile. $1^{\text {er }}$ fascicule: Neuroptéridées. 58 pp. Paris.

BoHLIN, B. 1971. Late Palaeozoic plants from Yüerhhung, Kansu, China. The Sino-Swedish Expedition, Publication 51. IV. Palaeobotany 1. I - 150 pp., II - pls I-XXV, 296 figs. Sven Hedin Foundation, Stockholm.

BRONGNIART, A. 1831. Histoire des végétaux fossiles ou recherches botaniques et géologiques sur les végétaux renfermées dans les diverses couche du globe 1(5), 209-248. G. Dufour \& E. d'Ocagne, Paris.

Brousmiche Delcambre, C., Mercier, D. \& CoQuel, R. 1996. Révision de la flore Carbonifère du Briançonnais. Implications stratigraphiques. I ire partie: Vallée de la Durance au sud de Briançon. Palaeontographica, Abteilung B 239(4-6), 77-107.
Cleal, C.J. 2002. Two new late Carboniferous Neuropteris species (Medullosales) from Saarland, Germany and their palaeobiogeographical significance. Botanical Journal of Linnean Society 139, 193-205. DOI 10.1046/j.1095-8339.2002.00056.x

CLEAL, C.J. \& LAVEINE, J.-P. 1988. The juvenile frond of the Middle Carboniferous pteridosperm Paripteris Gothan. Géobios 21(2), 245-250. DOI 10.1016/S0016-6995(88)80021-4

ClEAL, C.J. \& SHUTE, C.H. 1992. Epidermal features of some Carboniferous neuropteroid fronds. Review of Palaeobotany and Palynology 71, 191-206. DOI 10.1016/0034-6667(92)90162-A

Cleal, C.J. \& ShUTE, C.H. 1995. A synopsis of neuropteroid foliage from the Carboniferous and Lower Permian of Europe. Bulletin of the Natural History Museum 51(1), 1-52.

ClEAL, C.J. \& ZODROW, E.L. 1989. Epidermal structure of some medullosan Neuropteris foliage from the middle and upper Carboniferous of Canada and Germany. Palaeontology 32(4), 97-106.

Crookall, R. 1959. Fossil plants of the Carboniferous rocks of Great Britain; second section. Memoirs of the Geological Survey of the Great Britain. Palaeontology 4(2), 85-216.

DABER, R. 1963. Sind die imparipinnaten Neuropteriden oder die paripinnaten Neuropteriden morphophylogenetisch fortgeschrittener? Geologie (Berlin) 12, 1210-1218.

DiMichele, W.A., Phillips, T.L. \& PFEFFERKoRn, H.W. 2006. Paleoecology of Late Paleozoic pteridosperms from tropical Euramerica. Journal of the Torrey Botanical Society 133(1), 83-118. DO] 10.3159/1095-5674(2006)133[83:POLPPF]2.0.CO;2

Gothan, W. 1941. Paläobotanische Mitteilungen 5-7. Paläontologische Zeitschrift 22, 424-438.

Gothan, W. 1953. Die Steinkohlenflora der westlichen paralischen Steinkohlenreviere Deutschlands. Beihefte zum Geologischen Jahrbuch 10, 1-83.

HAVLENA, V. 1953. Neuropteridy českého karbonu a permu. (The Neuropterides of the Carboniferous and Permian of Bohemia.) Rozpravy Ústředního ústavu geologického 16, 5-88, 131-168.

HAVLENA, V. 1956. Cyklická sedimentace v žacléřských vrstách (Cyclical sedimentation in the Žaclér Beds). Rozpravy Československé akademie věd, Řada matematicko-prírodních věd 66(5), 1-57.

IWANIW, E. 1985. Floral palaeoecology of debris flow dominated valley - fill deposits in the Lower Cantabrian of NE León, NW Spain. Anals da Faculdade de Ciencias do Porto 64, 283-357.

JOSTEN, K-H. 1991. Die Steinkohlen-Floren Nordwestdeutschlands. Fortschritte in der Geologie von Rheinland und Westphalen 36, 1-434.

KERP, H. 1990. The study of fossil gymnosperms by means of cuticular analysis. Palaios 5, 548-549. DOI 10.2307/3514861

KERP, H. \& KRINGS, M. 1999. Light microscopy of fossil cuticles, 52-56. In JONES, T.P. \& RowE, N.P. (eds) Fossil plants and spores. Modern techniques. Geological Society, London.

LAVEINE, J.-P. 1967. Etudes géologiques pour l'atlas de Topographie souterraine. I. Flore fossile. 5. Contribution à l'étude de la flore du terrain houiller. Les Neuropteridées du Nord de la France. 344 pp. Service Houillers du Basin du Nord et du Pas-de-Callais, Lille.

LAVEINE, J.-P. 1971. Sporomorphes in situ de quelques Parispermées (Neuroptéridées) du Carbonifère. Annales de la Société géologique du Nord 91(2), 155-173. 
LAVEINE, J.-P. 1997. Synthetic analysis of the Neuropterids. Their interest for the decipherment of Carboniferous palaeogeography. Review of Palaeobotany and Palynology 95(1-4), 155-189. DOI 10.1016/S0034-6667(96)00033-4

LAVEINE, J.-P., Lemoigne, Y. \& ZHANG, S.-Z. 1993. General characteristics and palaeobiogeography of the Parispermaceae (genera Paripteris Gothan and Linopteris Presl), Pteridosperms from the Carboniferous. Palaeontographica, Abteilung $B$ 230(1-6), 81-139.

LAVEINE, J.-P., ZHANG, S. \& LEMOIGNE, Y. 2000. Palaeophytogeography and palaeogeography on the basis of examples from the Carboniferous. Revue de Paléobiologie 19(2), 409-425.

LAVEINE, J.-P., ZHANG, S., LiU, L., AN, D., ZHENG, Q., CAO, J. \& LEMoIgne, Y. 2003. The late Palaeozoic floras of the Hotan area (Xinjiang Uygur Autonomous Region, Northwest China), and their palaeogeographical significance. Revue de Paléobiologie 22(2), 473-559.

Libertín, M., DAŠKOVÁ, J., OPLUŠTIL, S., BEK, J. \& NADER, E. 2009. A palaeoecological model for a vegetated early Westphalian intramontane valley (Intra-Sudetic Basin, Czech Republic). Revue of Palaeobotany and Palynology 155, 175-203. DOI 10.1016/j.revpalbo.2008.07.002

MIALL, A.D. 1985. Architectural element analysis: a new method of facies analysis applied to fluvial deposits. Earth Science Reviews 22, 261-308.

NĚMEJC, F. 1933. Floristicko-stratigrafické studie o poměrech v uhelných revírech u Žacléře, Svatoňovic a Ždárků (blíže Hronova). [Stratigraphical and floristical studies in the Carboniferous of the coal districs of Žaclér (Schatzlar) Svatoňovice (Schwadowitz) and Ždárky (near Hronov).] Věstník Královské České společnosti nauk, Tř́da II, 1-33.

NĚMEJC, F. 1953. Úvod do floristické stratigrafie kamenouhelných oblastí ČSR. 173 pp. Academia, Praha.

NĚMEJC, F. \& ŠETLíK, J. 1950. Nové příspěvky k poznání floristicko-stratigrafických poměrů žacléřského souvrství v uhelných revírech u Žacléře a u Markoušovic. (Nouvelle contribution à l'etude des conditions floristiques et stratigraphiques de la série houillère de Žacléř dans les districts de Žacléř et de Markoušovice.) Věstník Státního geologického ústavu Československé republiky 25, 261-278.

POTONIÉ, H. 1899. Lehrbuch der Pflanzenpalaeontologie mit besonderer Rücksicht auf die Bedürfnisse des Geologen. Dümmler, Berlin.

PURKYŇOVÁ, E. 1986. Floristická zonálnost žacléřského souvrství v důlním poli Dolu Šverma u Žacléře (vnitrosudetská pánev). [Die floristische Zonalität der Žaclér-Formation im neuen Kohlenfeld der Zeche Šverma bei Žacléř (Innensudetisches Becken).] Časopis Slezského muzea Opava A 35, 57-83.

Rieger, Z., Holub, V., KrejČí, B. \& ProuZA, V. 1962. Geologický profil jámy Jan dolu Jan Šverma v Žaclérí (Geological section of the pit Jan of the Jan Šverma mine in Žaclér). 26 pp. Manuscript, Archiv of the Czech Geological Survey, Praha.

SpuDIL, J. 1999. Group of Seams of the Šverma Mine at Žaclér (Intra-Sudetic Basin). Acta Universitatis Carolinae, Geologica 43(4), 589-598.

STERNBERG, K.H. VON 1821. Versuch einer geognostisch botanischen Darstellung der Flora der Vorwelt. Bd. I., Hft. 2.33 pp., tent. I-XLII. F. Fleischer, Leipzig.
STERNBERG, K.H. VON 1825. Versuch einer geognostisch botanischen Darstellung der Flora der Vorwelt. Bd. I., Hft. 4.48 pp., tent. I-XLII. Ernst Brenck's Wittwe, Regensburg.

Stockmans, F. 1933. Les Neuroptéridées des bassins houillers belges. $1^{\text {ire }}$ partie. Mémoires du Musée Royal d'Histoire Naturelle de Belgique 5, 1-61.

SzE, H.C. 1930. Zu Schenks Publikationen über die ostasiatische Permokarbon-Flora. I. Teil. Memoirs of the National Research Institute of Geology (Academia Sinica) 9, 1-34.

SzE, H. \& LEE, H. 1946. Paleozoic plants from Ninghsia. Bulletin of the Geological Society of China 25, 227-260.

ŠETLíK, J. 1977. Fytopaleontologie, 123-130. In TÁSLER, R. (ed.) Geologie české části vnitrosudetské pánve (Geology of the Bohemian part of the Intra-Sudetic Basin). Ústřední ústav geologický, Praha.

ŠIMƯNEK, Z. 2007. Cuticular analysis of medullosan pteridosperms from the Radnice Member (Pennsylvanian) of the Central and Western Bohemian basins (Czech Republic), 389-401. In WONG, T.E. (ed.) Proceedings of the XV $V^{\text {th }}$ International Congress on Carboniferous and Permian Stratigraphy, Utrecht, 10-16 August 2003. Royal Dutch Academy of Arts and Sciences, Amsterdam.

ŠIMU゚NEK, Z. \& LIBERTÍN, M. 2006. Cordaites schatzlarensis sp. nov. and Samaropsis newberryi (Andrews) Seward from the Wesphalian (Carboniferous) of the Žaclér area (Czech Republic). Revue of Palaeobotany and Palynology 138, 43-62. DOI 10.1016/j.revpalbo.2005.10.001

TÁSLER, R., ČADKOVÁ, Z., DVOŘ́́K, J., FEDIUK, F., CHALOUPSKÝ, J., JeTEl, J., Kaiserová-KalibovÁ, M., ProuZA, V., SCHOVÁNKOVÁ-HRDLIČKOVÁ, D., STŘEDA, J., STŘíDA, M. \& ŠETLÍK, J. 1979. Geologie české části vnitrosudetské pánve (Geology of the Bohemian part of the Intra-Sudetic Basin). 296 pp. Ústřední ústav geologický, Praha.

WAGNER, R.H. 1962. A brief review of the stratigraphy and floral succession of the Carboniferous in NW Spain, 753-762. Compte Rendu du Quatrième Congrès pour l'avancement des études de Stratigraphie et de Géologie du Carbonifère, Heerlen 15-20 Septembre 1958, Tome III. Maastricht.

WAGNER, R.H. 1984. Megafloral Zones of the Carboniferous, 109-134. Compte Rendu Neuvième Congrès International de Stratigraphie et de Géologie du Carbonifère, Washington and Champaign/Urbana, 1979, 2.

WARTMANN, R. 1969. Studie über die papillen-förmigen Verdickungen auf der Kutikule bei Cordaites an Material aus dem Westphal C des Saar-Karbons. Argumenta Palaeobotanica 3, 199-207.

WHITE, D. 1900. The stratigraphic succession of the fossil floras of the Pottsville Formation of the Southern Anthracite Coal Field, 749-920, pl. 188-193. 20 Annual Report of the U.S. Geological Survey, Pt. II. Washington.

WNUK, C. \& PFEFFERKORN, H.W. 1984. The life habits and paleoecology of Middle Pennsylvanian medullosan pteridosperms based on an in situ assemblage from the Bernice Basin (Sullivan County, Pennsylvania, USA). Revue of Palaeobotany and Palynology 41, 329-351. DO] 10.1016/0034-6667(84)90053-8

ZHANG, S., HuO, F., CAO, J., LIU, Z., LAVEINE, J.-P. \& LEMOIGNE, Y. 1993. The Carboniferous flora of Zhongning district, Ninxia Region, North China. Revue de Paléobiologie 6, 1-93. 